\section{(1)}

CrossMark

\title{
B-blockers in pulmonary arterial hypertension: evolving concepts of right heart failure
}

\author{
Frances S. de Man $^{1}$ and M. Louis Handoko ${ }^{2}$
}

Affiliations: 'Dept of Pulmonology, VU University Medical Center/Institute for Cardiovascular Research, Amsterdam, The Netherlands. ${ }^{2}$ Dept of Cardiology, VU University Medical Center/Institute for Cardiovascular Research, Amsterdam, The Netherlands.

Correspondence: Frances de Man, VU University Medical Center, Amsterdam, The Netherlands. E-mail: fs.demandavumc.nl

\section{0}

@ERSpublications

Beta-blockers can be used safely by some PAH patients with comorbidities such as arrhythmias or hypertension http://ow.ly/P2JHg

Current guidelines advise against the use of $\beta$-blockers in pulmonary arterial hypertension (PAH) to avoid systemic hypotension [1]. In addition, PAH patients have a fixed stroke volume, and are therefore highly dependent on heart rate to increase their cardiac output [2-4]. Indeed, Provencher et al. [5] showed that withdrawal of $\beta$-blockers significantly improved exercise capacity in portopulmonary hypertension. PEACOCK and Ross [6] described another case of portopulmonary hypertension, in which the use of a $\beta$-blocker to treat a supraventricular tachycardia in an already haemodynamically unstable patient was nearly fatal.

Interestingly, patients with left heart failure also have a relatively fixed stroke volume [3, 7]. However, in this case, $\beta$-blocker therapy (together with angiotensin-converting enzyme (ACE) inhibition) is considered the cornerstone of treatment [8]. How can we explain this discrepancy?

PACKer [9] elegantly described the change in perspective on heart failure over the past 50 years. Until the 1960s, heart failure was solely regarded as an oedematous disorder, and the use of diuretics was central in the treatment. In the 1980s this view was extended with the cardiocirculatory model, in which heart failure was also viewed as a haemodynamic disorder. This led to the use of peripheral vasodilators and the development of positive inotropic agents. Although these agents effectively reduced symptoms, later it was consistently demonstrated that they increased mortality. Therefore, the conceptual view was adjusted again in the 1990s, and nowadays heart failure is also considered a neurohormonal disorder. This is the basis for the treatment with $\beta$-blockers and ACE inhibitors.

We see a similar pattern emerging when looking at PAH-induced right heart failure, where more and more evidence is accumulating that might shift our conceptual framework from a solely haemodynamic to also a neurohormonal perspective. We have previously summarised the pathophysiological relevance of the neurohormonal axis in PAH $[10,11]$. In short, in PAH patients, sympathetic nervous system activity is increased and correlates with prognosis [12-17]. In addition, local changes in $\beta$-adrenergic receptor signalling of the right ventricular myocardium of PAH patients have been demonstrated [18-20]. Furthermore, in experimental PAH-models, $\beta$-blocker therapy reversed cardiac remodelling and improved outcome [21-23].

Whereas it is much too early to advocate $\beta$-blockers treatment to reverse right heart failure in patients, signals are emerging that the dangers of $\beta$-blockers in $\mathrm{PAH}$ patients are much smaller than previously thought. In this issue of the European Respiratory Journal, BANDYOPADHYAY et al. [24] describe the outcomes of $\beta$-blocker use in the largest PAH cohort thus far. Most patients received $\beta$-blockers for treatment of arrhythmias, presumed congestive cardiac failure or hypertension. Main reasons to

Received: March 302015 | Accepted after revision: April 092015

Conflict of interest: None declared.

Copyright OERS 2015 
discontinue $\beta$-blockers were systemic hypotension, shortness of breath or volume overload. In this retrospective analysis, they did not find detrimental effects on survival or time-to-clinical worsening, when comparing $\beta$-blockers use versus no $\beta$-blocker use. The authors are to be commended for providing unique long-term follow-up data. The overall findings are consistent with other retrospective reports [25-27], but are in contrast to earlier case series [5]. This may be explained by the difference in patient population (portopulmonary hypertension versus idiopathic PAH or PAH secondary to connective tissue disease) and the more frequent use of third generation $\beta$-blockers (propranolol versus metropolol/carvedilol). Interestingly, the data at 10 -year follow-up even suggest a little survival benefit, although this could be a type I error. The dataset was too small for a meaningful comparison between the different types of $\beta$-blockers. One could argue that based on these data, there is no reason to discontinue $\beta$-blockers, when prescribed for other indications than PAH. This fits to the perspective of $\mathrm{PAH}$-induced right heart failure that neurohormonal factors may play a role.

The study by BANDYOPADHYAY et al. [24] has taught us that when comorbidities exist, such as arrhythmias or hypertension, $\beta$-blockers can be used relatively safely in a considerable number of PAH patients. However, clinical evidence that $\beta$-blockers are to be used for the treatment of right heart failure in these patients is currently lacking. Two small pilot studies have provided some interesting signals [28, 29], but an adequately powered randomised clinical trial is urgently needed.

\section{References}

1 Galiè N, Hoeper MM, Humbert M, et al. Guidelines for the diagnosis and treatment of pulmonary hypertension. Eur Respir J 2009; 34: 1219-1263.

2 Provencher $\mathrm{S}$, Chemla $\mathrm{D}$, Hervé $\mathrm{P}$, et al. Heart rate responses during the 6-minute walk test in pulmonary arterial hypertension. Eur Respir J 2006; 27: 114-120.

3 Groepenhoff $\mathrm{H}$, Westerhof $\mathrm{N}$, Jacobs $\mathrm{W}$, et al. Exercise stroke volume and heart rate response differ in right and left heart failure. Eur J Heart Fail 2010; 12: 716-720.

4 Vonk-Noordegraaf A, Westerhof N. Describing right ventricular function. Eur Respir J 2013; 41: 1419-1423.

5 Provencher S, Herve P, Jais X, et al. Deleterious effects of beta-blockers on exercise capacity and hemodynamics in patients with portopulmonary hypertension. Gastroenterology 2006; 130: 120-126.

6 Peacock A, Ross K. Pulmonary hypertension: a contraindication to the use of $\beta$-adrenoceptor blocking agents. Thorax 2010; 65: 454-455.

7 Sullivan MJ, Higginbotham MB, Cobb FR. Exercise training in patients with severe left ventricular dysfunction. Hemodynamic and metabolic effects. Circulation 1988; 78: 506-515.

8 McMurray JJV, Adamopoulos S, Anker SD, et al. ESC Guidelines for the diagnosis and treatment of acute and chronic heart failure 2012: The Task Force for the Diagnosis and Treatment of Acute and Chronic Heart Failure 2012 of the European Society of Cardiology. Developed in collaboration with the Heart Failure Association (HFA) of the ESC. Eur Heart J 2012; 33: 1787-1847.

9 Packer M. How should physicians view heart failure? The philosophical and physiological evolution of three conceptual models of the disease. Am J Cardiol 1993; 71: 3C-11C.

10 De Man FS, Handoko ML, Guignabert C, et al. Neurohormonal axis in patients with pulmonary arterial hypertension: friend or foe? Am J Respir Crit Care Med 2013; 187: 14-19.

11 Handoko ML, de Man FS, Allaart CP, et al. Perspectives on novel therapeutic strategies for right heart failure in pulmonary arterial hypertension: lessons from the left heart. Eur Respir Rev 2010; 19: 72-82.

12 Velez-Roa S, Ciarka A, Najem B, et al. Increased sympathetic nerve activity in pulmonary artery hypertension. Circulation 2004; 110: 1308-1312.

13 McGowan CL, Swiston JS, Notarius CF, et al. Discordance between microneurographic and heart-rate spectral indices of sympathetic activity in pulmonary arterial hypertension. Heart Br Card Soc 2009; 95: 754-758.

14 Wensel R, Jilek C, Dörr M, et al. Impaired cardiac autonomic control relates to disease severity in pulmonary hypertension. Eur Respir J 2009; 34: 895-901.

15 Nootens M, Kaufmann E, Rector T, et al. Neurohormonal activation in patients with right ventricular failure from pulmonary hypertension: relation to hemodynamic variables and endothelin levels. J Am Coll Cardiol 1995; 26: $1581-1585$.

16 Mak S, Witte KK, Al-Hesayen A, et al. Cardiac sympathetic activation in patients with pulmonary arterial hypertension. Am J Physiol Regul Integr Comp Physiol 2012; 302: R1153-R1157.

17 Ciarka A, Doan V, Velez-Roa S, et al. Prognostic significance of sympathetic nervous system activation in pulmonary arterial hypertension. Am J Respir Crit Care Med 2010; 181: 1269-1275.

18 Bristow MR, Ginsburg R, Umans V, et al. Beta 1- and beta 2-adrenergic-receptor subpopulations in nonfailing and failing human ventricular myocardium: coupling of both receptor subtypes to muscle contraction and selective beta 1-receptor down-regulation in heart failure. Circ Res 1986; 59: 297-309.

19 Rain S, Handoko ML, Trip P, et al. Right ventricular diastolic impairment in patients with pulmonary arterial hypertension. Circulation 2013; 128: 2016-2025.

20 Rain S, Bos Dda SG, Handoko ML, et al. Protein changes contributing to right ventricular cardiomyocyte diastolic dysfunction in pulmonary arterial hypertension. J Am Heart Assoc 2014; 3: e000716.

21 De Man FS, Handoko ML, van Ballegoij JJM, et al. Bisoprolol delays progression towards right heart failure in experimental pulmonary hypertension. Circ Heart Fail 2012; 5: 97-105.

22 Bogaard HJ, Natarajan R, Mizuno S, et al. Adrenergic receptor blockade reverses right heart remodeling and dysfunction in pulmonary hypertensive rats. Am J Respir Crit Care Med 2010; 182: 652-660.

23 Perros F, Ranchoux B, Izikki M, et al. Nebivolol for improving endothelial dysfunction, pulmonary vascular remodeling, and right heart function in pulmonary hypertension. J Am Coll Cardiol 2015; 65: 668-680. 
24 Bandyopadhyay D, Bajaj NS, Zein J, et al. Outcomes of $\beta$-blocker use in pulmonary arterial hypertension: a propensity-matched analysis. Eur Respir J 2015; 46: 750-760.

25 Thenappan T, Roy SS, Duval S, et al. $\beta$-blocker therapy is not associated with adverse outcomes in patients with pulmonary arterial hypertension: a propensity score analysis. Circ Heart Fail 2014; 7: 903-910.

26 So PP-S, Davies RA, Chandy G, et al. Usefulness of beta-blocker therapy and outcomes in patients with pulmonary arterial hypertension. Am J Cardiol 2012; 109: 1504-1509.

27 Moretti C, Grosso Marra W, D'Ascenzo F, et al. Beta blocker for patients with pulmonary arterial hypertension: a single center experience. Int J Cardiol 2015; 184: 528-532.

28 Grinnan D, Bogaard H-J, Grizzard J, et al. Treatment of group I pulmonary arterial hypertension with carvedilol is safe. Am J Respir Crit Care Med 2014; 189: 1562-1564.

29 Van Campen JSJA, De Boer K, Wagenaar M, et al. Beta-blocker therapy in patients with idiopathic pulmonary arterial hypertension: a randomized controlled trial. Am J Respir Crit Care Med 2014; 189: A6569. 